\title{
The name of the apple
}

\author{
D.J. Mabberley, C.E. Jarvis and B.E. Juniper
}

\begin{abstract}
Mabberley, D.J. (Nationaal Herbarium Nederland, University of Leiden, The Netherlands, and Royal Botanic Gardens Sydney, Mrs Macquaries Road, Sydney, NSW, Australia 2000), Jarvis, C.E. (Department of Botany, The Natural History Museum, Cromwell Road, London SW7 5BD, UK), and Juniper, B.E. (Department of Plant Sciences, University of Oxford, South Parks Road, Oxford OX1 3RB, UK) 2001. The name of the apple. Telopea 9(2): 421-430. It is shown that the correct name to be applied to orchard apples (if Malus is to be maintained as a distinct genus) is, once again, Malus pumila Mill.: cultivars should be written as, e.g., Malus pumila 'Granny Smith'. Names used for apples by Linnaeus are typified (five neotypifications). The native apple of northern Europe is Malus sylvestris (L.) Mill., though many 'wild' apples there are derived from cultivated forms of the Asiatic M. pumila.
\end{abstract}

\section{Introduction}

In preparing an account of the watercolour drawings of Arthur Harry Church (Mabberley 2000), the first author was confronted with the fact that there is no consensus on the Latin binomial to be applied to the common apple. Despite apples being the most important temperate fruit crop, not only in Australia, but worldwide (Zohary \& Hopf 1988: 151), this seemingly simple matter has not been resolved.

For some 70 or 80 years, apples have been referred to the genus Malus Mill. (Rosaceae), though Church, the Edwardian botanist and artist, like most of his contemporaries, worldwide, referred to it as Pyrus malus L.

\section{Apples in Australia}

No Malus (or Pyrus) species is native in Australia but, since early colonial times, apples have become naturalised and some cultivars of world importance have been raised here. The most famous is, perhaps, 'Granny Smith'. By 1924, Herbert Rumsey, a Dundas orchardist and local historian (Rumsey 1924, also Sydney Morning Herald 6 Nov 1936 [see Tucker \& Co. [1938]]) could write that the 'Granny Smith' apple was "the most valuable of all apples grown in Australia". However its origin was even by then anecdotal, according to those who could remember the first grower, Maria Ann Smith (1799-1870), née Sherwood, of Peasmarsh, Sussex, UK, who had arrived in Australia in November 1838 (Spurway n.d.). Her husband, Thomas, bought land in what is now Eastwood, a suburb of Sydney, in 1855 and 1856. According to the story related to Rumsey, Mrs Smith returned from the Sydney Markets with some gin crates, which had contained the rotting remains of some 'French Crab' apples from Tasmania. She tipped the mess into a creek on her land and, by 1868, she was able to show visitors the resulting tree from which all 'Granny Smith' apple trees have been derived.

Until recently, 'Granny Smith', like all orchard apples, was thought to have had a complex hybrid ancestry involving a number of species native in Central Asia, M. sieversii (Ledeb.) M. Roem. being important in the lineage. DNA studies and fieldwork (Robinson et al., 2001) have shown on the one hand that there is no evidence from nuclear ITS and chloroplast matK sequence analysis to support the view that 
hybridisation with other Malus spp. took place during the westerly migration of the orchard apple and, on the other, that ' $M$. sieversii' is just one aspect of very variable but monospecific wild apple populations in Central Asia. In these populations forms can be found resembling the major groups of cultivated apples seen in Europe and taken thence around the world; for a popular account of these stands where 'every tree is a different variety', see Browning (1998: 60).

\section{Latin names for orchard apples}

'Granny Smith' is therefore a cultivar of that Asiatic wild Malus, but what is the correct binomial to apply to the species? It may seem almost incredible to laypeople that scientists cannot agree on the name for so common and important a plant as the apple (cf. Corner 1946), for, despite the fact that some authors have recently settled on (the illegitimate) name, M. domestica Borkh., following Korban \& Skirvin (1984), though the most recent published opinion (Kartesz \& Gandhi 1992) argues for M. sylvestris, there is disarray in the popular as well as systematic and floristic literature. In current use are a number of names, used as species or as hybrid names - M. communis Desf. (e.g. the International Book of Fruit and used consistently in many French books in the nineteenth century), M. domestica (Mansfeld 1986: 355-63; Given \& Sykes 1988; Terpó 1988; Harden \& Rodd 1990; Vaughan \& Geissler 1997: 52-61), M. pumila (Rehder 1949; Zohary \& Hopf 1988, 1994; Le Bon Jardinier ed. 153 1992; Ghjora \& Panigrahi 1995), $M$. sylvestris (Browicz 1972; Symon 1986; Maxwell et al. 1988, as subsp. mitis); yet other names have been used in the past.

\section{Linnaeus's apple names}

Most of these names ultimately rest on names published in the works of Linnaeus, who included apples under the genus Pyrus. It is therefore necessary to examine Linnaeus's names and to typify them, thereby typifying Malus names based on them. These typifications refer to the Linnaean names and do not affect 'standards' for cultivar names.

As with citrus fruit (Mabberley 1997b), DJM needed to clarify this matter for updating The Plant-book (Mabberley 1987, 1997a), as well as for the book on Church's work, and approached CEJ, coordinator of the Linnaean Plant Name Typification Project, and BEJ, pomologist and supervisor of the DNA work in Oxford.

2. PYRUS foliis ferratis, pomis bafi concavis. Hort.cliff. Malns. 189. Hort. upf. г 30 . Fl. Suec. 402. Mat. med. 237. Roy. lugdb. 266. Hall. belv. $35 \mathrm{t}$.

Malus fylveftris. Baub. pin. 435. Dod, pempt. 790. fylveftris.

B. Malus pumila, quæ potius frutex quam arbor.Bawh. paradifiaca. pin. 433.

$\gamma$. Malus prafomila. Baub. pin. 433. prafomila.

$\delta$. Malus fativa, fructu fanguinei coloris ex auftero fub- rubelliana. dulci. Toursef. inft. 635 .

\&. Mala curtipendula dicta. Baub. bift. I.p. 21 . ceftiana.

Epirotica.
Habitat in Europa. $\hbar$

Fig. 1. Linnaeus's entry for Pyrus malus. 
Pyrus malus L., Sp. Pl.: 479, 1200 (1753) = Malus pumila Mill., Gard. Dict. Ed. 8: Malus n. 3 (1768), (unidentified cv.)

Type: Cultivated in Europe, Herb. Linn. 647.3 (LINN, fiche seen; lecto selected by Ghora \& Panigrahi, Fam. Rosaceae in India 2: 375, t. 72A (1995)).

Malus pumila is the earliest specific name in Malus for any plant, wild or cultivated, derived from the variable wild apple populations of Central Asia. See below.

Some, at least, of the varieties Linnaeus recognised seem to represent what might be thought of today as cultivar groups, now 'typified' by particular cultivars:

Pyrus malus L. var. cavillea L., Sp. Pl. ed. 2, 1: 686 (1762) = Malus pumila Mill. 'Calville Rouge d'Automne'

\section{cavillea. $\zeta$. Mala fativa, fructu magno intenfe rubente, viola} odore. Tournef. inft. 635 .

Fig. 2. Linnaeus's entry for Pyrus malus var. cavillea.

Type: Cultivated at National Fruit Collection [Accession 1949011 - ex W. Barnes, Bexhill, England, Oct. 1949], Brogdale, Faversham, Kent, England, 20 May 1999, E-J. Lamont 1309 p.p.(fl.), (neo, designated here: NSW; isoneo: BM, FHO; epitype [same tree, lvs, 5 Aug. 1999, E.-J. Lamont 1309 p.p]: NSW; iso-epi: BM, FHO).

There is no extant original material; none survives in any of Linnaeus's herbaria, and although Linnaeus cited a Tournefort binomial, it cannot be linked to anything other than a generalised illustration describing a number of different taxa. He did not study Tournefort's specimens (in any case no material of this taxon survives in Tournefort's herbarium at P). Poiret (1804) noted, "On distingue le calvil d'automne \& le calvil blanc ou calvil d'été ", grouping them under 'Le Calvil' with Linnaeus's and Tournefort's names as synonyms.

Although it was being grown in at least South Australia around 1916, this apple is apparently no longer in Australia, though other 'Calville' cultivars are still found here (Clive Winmill, pers. comm.).

Pyrus malus L. var. cestiana L., Sp. Pl. 1: 479 (1753) = Malus pumila Mill. 'CourtPendu Plat'

Type: Cultivated, from material grown in Badger's Keep Nursery, Chewton, Victoria, Australia, 31 Mar. 1999, fr. [dried and in spirit], D.J. Mabberley, K. Robertson \& C. Winmill 2474 (neo designated here: NSW; isoneo: BM, FHO, L, MEL).

There is no extant original material in any of the Linnaean herbaria. Linnaeus cited Bauhin \& Cherler (1650: 21) but that is not accompanied by an illustration, nor can any supporting material be found at UPS, or at BAS (Heinz Schneider, pers. comm.). A neotype has therefore been designated. This apple has been known in cultivation for some 400 years.

Pyrus malus L. var. epirotica L., Sp. Pl. 1: 480 (1753) = Malus pumila Mill. ‘Pomme $\mathrm{d}^{\prime} \mathrm{Api}{ }^{\prime}$

Type [icon]: 'Pomme d'Api' - R. Hogg, Herefordshire Pomona t. 74, f. 2 (1876-85) (neotype selected here). 
There is no extant original material in any of the Linnaean herbaria. The name is based on a description (without any illustration) of Poma orbiculata by Dioscorides (1552). Poiret (l.c.) added the Tournefort synonym Malus sativa, fructu orbiculata, odorato ... Pomme Rose and referred the plant to his 'La pomme-rose', noting 'Cette pomme est toute ronde, d'une couleur de rose assez jolie, d'une faveur parfumée'. 'Le gros api, pomme rose' was listed by Audibert Frères (1825) in their catalogue and considered a form of the 'Pomme d'Api' by Decaisne \& Naudin (n.d.: 433, t. 168). Selection of the 'Pomme d'Api' was attributed to the Greeks with Claudius Appius saying it came from the Peloponnese (Société National d'Horticulture de France, Section Pomologique [1907: 454]).

Although grown in Australia up to World War I, as the Lady Apple, it is apparently no longer in cultivation here, though allegedly represented at Brogdale, England (Clive Winmill, pers. comm.) but we have seen no European material, hence our choosing to designate an (excellent) illustration as neotype.

Pyrus malus L. var. paradisiaca L., Sp. Pl. 1: 479 (1753) = Malus pumila Mill. 'Malling VIII' ('M8').

Type: Cultivated ('Malus M8 rootstock'), Horticultural Research International East Malling, Kent, England, 25 April 2000, fl., A. King s.n (neo designated here: NSW; isoneo: $\mathrm{BM}, \mathrm{FHO})$.

There is no extant original material in any of the Linnaean herbaria. The name is based on a polynomial from Bauhin (1623), but there are no specimens in the Burser Herbarium (UPS) associated with it. Bauhin in turn cited Bock who referred to it as 'Paradisian, in German Paradeisopffel'. Worlidge (1676: 159) wrote, 'The Paradise Apple is a curious Fruit, produced by grafting a Permain [sic] on a Quince'. It is difficult to be sure whether early authors were using the name for the grafted plant as a whole or as it was later used as the common name applied worldwide to some grafting stocks. The epithet 'Paradise' is associated with things Persian, the word being derived from the Old Persian pairi daiza meaning a walled garden, suggesting an origin for the plant, many authors considering it introduced to Britain from Armenia via France.

Linnaeus himself may not have had any particular selection of dwarfing stock in mind and there was great confusion about the stocks in any case (Hatton 1917). According to Carrière (1879), there were three sorts of grafting stocks in use on the Continent of Europe in the nineteenth century - franc, doucin and paradis, of which the latter two were propagated by cuttings; Carrière added that the old 'Paradis ordinaire' (Malling VIII, though Malling IV was common in Holland and Germany), which was not reliable under all conditions, was in his time being replaced by the 'Paradis jaune (de Metz)', i.e. Malling IX ('M9') (Hatton 1917). The latter, which was selected by the firm of Simon-Louis at Plantières-les-Metz in 1828, is the common stock now used in Australia. Malling VIII has probably never been grown here and we have found no herbarium material of it from any country, so we have had specimens from the East Malling stock prepared to serve as neotype.

Pyrus malus L. var. prasomila L., Sp. Pl.: 479 (1753) = Malus pumila Mill. 'Reinette Franche'

Type: Cultivated at National Fruit Collection, Brogdale, Faversham, Kent, England [Accession 1947288 ex A. Viennois, Odenas, Rhone, France, Mar. 1947], 20 May 1999 (fls), E-J. Lamont 1308 p.p. (neo designated here: NSW; isoneo: BM, FHO; epitype [same tree, 5 Aug. 1999 (lvs), E.-J. Lamont 1308 p.p.]: NSW; iso-epi: BM, FHO). 
There is no extant original material in any of the Linnaean herbaria. The name is based on a polynomial from Bauhin (1623) but there are no associated specimens in the Burser Herbarium (UPS). The Bauhin reference is to the 'Granicher' apple. Known from before 1650, it is Tournefort's Malus sativa, fructu subrotundo, è viridi pallescente, acido-dulci and Renette blanche, ou franche (Tournefort 1700: 634), referred to 'Renette Blanche' (white or French Renette) by Miller (1768). Linnaeus himself annotated his own copy (in LINN) of Species plantarum with 'Renette' after 'Bauh. pin. 433'. Desfontaines (1809: 140) had var. prasomila for the 'reinette' and Poiret (1.c.) refers both Tournefort's and Linnaeus's names to his 'La reinette', adding, 'C'est la plus estimée de toutes: on en distingue de plusiers sortes: la reinette blanche ... la reinette grise ... la reinette franche'. According to the Sociéte National d'Horticulture de France, Section Pomologique (1907: 510), 'Reinette commune' and 'Reinette blanche' are synonyms of 'Reinette Franche'.

Although several 'Reinettes' are grown in Australia, 'Reinette Franche' seems never to have been grown here, though it is still in England, e.g. at Brogdale, where the neotype material was gathered.

Pyrus malus L. var. rubelliana L., 1.c. = Malus pumila Mill. cv.

There is no extant original material in any of the Linnaean herbaria. The name is based on a polynomial from Tournefort (1700: 635), who, in turn cited Poma rubelliana of Dioscorides (1552: 252), which is the source of Linnaeus's epithet. Tournefort called such trees 'Pommes de Rouveau', 'rouveau' probably being an archaic French word for reddish (Aymonin, P, pers. comm.), cognate with Ruellius's name for Dioscorides' plant which Tournefort cites. Linnaeus took up very few of the horde of apple cultivars discussed by Tournefort, so this one must have seemed distinctive to him, though perhaps he was using the name to cover the pearmains of the time in general (see above). Poiret, l.c., referred both the Linnaean and Tournefortian names to his 'Le rouveau', and included the illustration 'Zahmer [= domestic] Apfel baum') of Blackwell (1750-52: t. 141), which was apparently of one of the standard pearmains of the period, and was referred here at least as early as the 1770s (Reichard [1779: 502], who wrote, 'Ce fruit est d'un rouge sanguin, assez agréable par sa saveur douce, aigrelette'). It is not discussed by Desfontaines (1.c.), and 'rouveau' does not appear in the French catalogues we have examined or in modern dictionaries. Perhaps the original 'Greek' plant of Disocorides is long lost.

Pyrus malus L. var. sylvestris L., Sp. Pl.: 479 (1753) = Malus sylvestris (L.) Mill.

Type: Latvia, 'Dist. Madonensis, prope villula Grasi', V. Langenfelds 105 (neo-: RIG, photo seen; selected by Langenfelds, Apple-trees: 186, 1991).

Desfontaines (1.c.) had Malus communis var. sylvestris for the 'sauvageon' but Moench (1794: 680) used M. sylvestris for Pyrus malus and Poiret (op. cit.: 560) included ' $M$. silvestris Bauh.' under M. communis. Indeed, in advance of the latest findings the recent problem over not using $M$. communis or $M$. domestica for the orchard apple largely stemmed from the interpretation of P. malus var. sylvestris L. Without a Greek letter in the protologue, var. sylvestris might appear to be referring to the 'typical' (autonymic) variety and might therefore be a superfluous name for var. malus (Kartesz \& Gandhi 1992). However, Dick Brummitt (K, pers. comm.), wrote, "my feeling is that [Linnaeus] had no concept of autonyms, and that any infraspecific epithet he published should be accepted as a validly published varietal name. I know that it is odd that he did not publish the alpha sign, but if he had done so I would feel that 'sylvestris' is still an atypical variety, and when he left out the sign I am not inclined to think that the epithet should be treated any differently ... Then I would be inclined to treat Miller's specific name as a new one". 
Dan Nicolson (US, pers. comm.) suggested, "Linnaeus did not view species as being composed of nothing but varieties alpha onward but what we would call "typical" he did not number. To this element he attached what he numbered (in Greek) what we call varieties that he sometimes named. I do not know why he did not number the alpha attachment but it, like the beta, gamma, delta, etc. varieties are not "typical" in the modern sense ... I note that Pyrus Malus, surely the cultivated taxon, would not have been called "sylvestris" (the forest or wild apple). By the same token, the preceding species involving the cultivated pear, Pyrus communis, surely should not be typified on an element Bauhin called Pyrus sylvestris and Linnaeus called [var.] pyraster (false pear)".

We agree: in this interpretation, var. sylvestris is therefore not a superfluous renaming of the 'typical' variety and can continue to be used for the native apple of Europe - as Malus sylvestris (L.) Mill. If the contrary view is taken, M. sylvestris Mill. is a new name for Pyrus malus L., i.e. it would be a contender for the name for the cultivated orchard apple, as used long ago by, e.g. Moench (1794), though perhaps he was then referring to apples in the wild that were derived from orchard apples. In this case, the European plant would have to bear a different name: this is not in the interests of nomenclatural stability. The synonymy for the native European tree is therefore:

Malus sylvestris (L.) Mill., Gard. Dict. Ed. 8: Malus n. 1 (1768).

Type: see above.

三Pyrus malus L. var. sylvestris L., Sp. Pl.: 479 (1753).

$\equiv$ M. communis Desf. var. sylvestris (L.) Desf., Hist. Arb. 2: 140 (1809), nom. illeg.

Europe to C Asia. This is a rare and rather invariable species armed with spines.

\section{The name of orchard apples}

In publishing Malus pumila, Miller (1768) cited as a synonym M. pumila quae potius frutex quam arbor Bauhin (1623: 433) and referred to the his plant as "Paradise Apple". This synonym is shared with Pyrus malus var. paradisiaca L. Although Miller did not explicitly cite Linnaeus's name, he "applied Linnaeus's method entirely" in the eighth edition of The gardeners dictionary (Miller 1768). Under the ICBN (Greuter et al., 2000), Arts 32. 1(c), 32. 3, 32. 4 and 32 Ex. 7, in citing the Bauhin polynomial and linking it to the Paradise Apple, Miller provided an indirect but clear reference to P. malus var. paradisiaca. We therefore accept $M$. pumila as a nomen novum for $P$. malus var. paradisiaca, with which it is therefore homotypic. Malus pumila is, in consequence, the correct binomial, in Malus, for the orchard apple and its wild antecedents. Commonly used names and the Linnaean names discussed above are included in the synonymy below ( ${ }^{*}=$ additions to Index Kewensis and other lists):

Malus pumila Mill., Gard. Dict. ed. 8: Malus n. 3 (1768); Rehder, Bibl. Cult. Trees Shrubs: 267 (1949).

Type: as for Pyrus malus var. paradisiaca (see above).

$\equiv$ P. malus L. var. paradisiaca L., Sp. Pl.: 479 (1753).

$\equiv$ M. paradisiaca (L.) Medik., Gesch. Bot.: 78 (1793), nom. superfl.

$\equiv$ M. communis Desf. var. paradisiaca (L.) Desf., Hist. Arb. 2: 140 (1809), nom. illeg.

$\equiv$ P. pumila (Mill.) Mill. ex Steud., Nomencl. Bot.: 670 (1821).

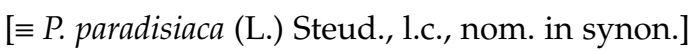

$\equiv$ M. paradisiaca (L.) Medik. var. pumila (Mill.) Koehne, Deut. Dendr.: 259 (1893), nom. illeg.

$\equiv$ M. pumila Mill. var. paradisiaca (L.) C.K. Schneid., Ill. Handb. Laubh. 1: 715 (1906). 
$\equiv$ P. malus L. var. pumila (Mill.) A. Henry in Henry \& Elwes, Trees Brit. Irel. 6: 1570 (1912), nom. superfl. pro P. malus var. paradisiaç $\equiv$ M. sylvestris (L.) Mill. var. paradisiaca (L.) L.H. Bailey, Hortus Sec.: 457 (1941).

$\equiv$ M. sylvestris (L.) Mill. subsp. paradisiaca (L.) Soó, Acta Bot. Acad. Sci. Hung. 18: 175 (1973). $\equiv$ M. praecox (Pall.) Borkh. var. paradisiaca (L.) Valev, Fl. Reip. Pop. Bulg. 5: 347 (1973). $\equiv$ M. domestica Borkh. var. paradisiaca (L.) Lich., Trudy Prikl. Bot. Genet. Selek. 52(3): 21 (1974), nom. illeg.

$\equiv$ M. domestica Borkh. subsp. pumila (Mill.) Likh., Fl. Kul't. SSSR 14: 69 (1983), nom. illeg. = P. malus L., Sp. Pl. 1: 479, 2: 1200 (1753).

Type: see above.

=Sorbus malus (L.) Crantz, Stirp. Austr. Fasc. 2: 57 (1763).

$\equiv$ M. sylvestris Moench, Meth.: 680 (1794); Karstesz \& Gandhi, Phytol. 73: 131 (1992); non (L.) Mill. (1768).

$\equiv$ M.* communis Desf., Fl. Atlantica 1: 398 (1798).

$\equiv$ M. domestica Borkh., Theor-Prakt. Handb. Forstbot. 2: 1271 (1803), nom. illeg., superfl.; Korban \& Skirvin, HortSci. 19: 177 (1984).

$\equiv$ Pyrenia malus (L.) [Clairv.], Man. Herb. Suisse: 162 (1811).

$\equiv$ Pyrus sylvestris Gray, Nat. Arr. Brit. Pl.: 2: 562 (1821), nom. superfl.

$\equiv$ M. pumila Mill. var. domestica (Borkh.) C.K. Schneid., Ill. Handb. Laubh. 1: 715, t. 396 (1906).

三P. pumila (Mill.) Steud. var. domestica (Borkh.) Asch. \& Graebner, Syn. Mitt. Fl. 6, 2: 77 (1906).

三 M. dasyphylla Borkh. var. domestica (Borkh.) Koidz., Acta Phyt. Geob. 3: 189 (1934).

Note. Of the names in Malus based on Pyrus malus L., and therefore on its type specimen, the earliest (but see P. malus var. sylvestris above) are M. communis Desf. (1798) and M. domestica Borkh. (1803). Malus communis, despite being published in a major Flora, has been overlooked (it is not listed in Index Kewensis for example) and M. domestica was long considered to be a species of Sorbus (see, e.g. , Index Kewensis). The latter, a superfluous name, has only relatively recently been resuscitated, though Borkhausen (1803) implied it was in use, if not in print, before 1803. Although earlier he (Borkhausen 1797) had followed Medikus (1793) in splitting off Malus from Pyrus, he himself certainly did not use $M$. domestica then. Index Londinensis lists Malus communis as published in 1797, though the cited plate actually appeared in 1794, but its accompanying letterpress with the name M. communis was not published in the work cited until 1819.

= Pyrus malus L. var. cestiana L., Sp. Pl.: 479 (1753).

Type: see above.

= Pyrus malus L. var. epirotica L., Sp. Pl.: 480 (1753).

Type: see above.

[झ P. epirotica (L.) Steud., 1.c., nom. in synon.]

= Pyrus malus L. var. prasomila L., Sp. P1.: 479 (1753).

Type: see above.

$\equiv$ Malus communis Desf. var. prasomila (L.) Desf., 1.c.

$\equiv$ P. parasomila Steud., op. cit: 671 (1821).

$\equiv$ P. prasomila (L.) Steud., 1.c.

$\equiv$ M.* prasomila (L.) Poit. \& Turpin in Duhamel, Traité nouv. éd. 5: t. 111 (1810 'prosomila'). 
= Pyrus malus L. var. rubelliana L., Sp. Pl.: 479 (1753).

Type: see above.

=Pyrus malus L. var. cavillea L., Sp. Pl. ed. 2, 1: 686 (1762).

Type: see above.

$\equiv$ Malus communis Desf. var. cavillea (L.) Desf., 1.c.

[” P. cavillea (L.) Steud., Nomencl. Bot.: 670 (1821), nom. in synon.]

$\equiv$ M. domestica Borkh. var. cavillea (L.) Likh., Fl. Kul't SSSR 14: 65 (1983).

= [? Malus vulgaris Pallas, Reise 3: 653 (1776), nom. nud.]

= Pyrus sieversii Ledeb., Fl. Alt. 2: 222 (1830).

Type: 'Siberia', [1790-4], J.E. Sievers s.n. (LE?, n.v.).

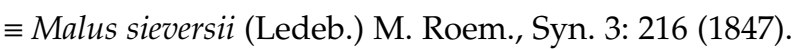

Native in Central Asia, M. pumila is now much restricted in the wild, but selected forms have been carried throughout the temperate world as orchard apples and become naturalised widely. Wildings in Europe include trees named in Floras $M$. acerba Mérat, for example.

It was the habit of early European voyagers to Australia to plant seeds of European crops, so that apple seeds may well have been sown before the First Fleet arrived in 1788. Cultivars growing in England about the time of the Fleet are listed in Weston (1775: 220), but others introduced to Australia then or before could have been picked up at ports of call on the voyages from Europe. Those apples likely to have been brought by the Fleet (Surrey Jacobs, NSW, pers. comm.) include M. pumila 'CourtPendu Plat' (see above), still grown, and 'French $\mathrm{Crab}^{\prime}$, from which arose 'Granny Smith'.

\section{Conclusion}

The foregoing demonstrates how intricate ascertaining the correct nomenclature for economic plants can be. In recent years there has been much ink spilled in ascertaining the correct name in Lycopersicon (Solanaceae) for the common tomato, L. esculentum Mill. (see Terrell et al., 1983), but all that has now been superseded in that the tomato has been returned to where Linnaeus had it - in Solanum, so that it is now S. lycopersicum L. once more (Spooner et al., 1993). Similarly, although Malus pumila is now, once again, seen to be the correct name in Malus for the common apple, it is likely that the narrowly defined genera of this group coming from folk taxonomy (Walters 1961), will also ultimately be recombined following phylogenetic work. In this case, the folk taxonomy was enshrined, for example, by Tournefort (as in citrus fruit [Mabberley 1997b] and the strawberry and its allies: Potentilla to include Fragaria), then rejected by Linnaeus, and later resurrected by Miller, Medikus and Jussieu.

In following the re-amalgamation of the other Rosaceous genera Amygdalus L., Armeniaca Scop., Cerasus Mill., Laurocerasus Duham., Padus Mill. and Persica Mill., into Prunus L., so that the name of the almond is once more referred to Prunus, as P. dulcis (Mill.) D.A. Webb, and that of the peach becomes P. persica L. once more, the name of the apple would then revert to just what Linnaeus (and most early C20 authors including Church) had - Pyrus malus L., or even Sorbus malus (L.) Crantz, with concomitant changes in the names of other species presently accommodated in Malus. 


\section{Acknowledgments}

We are indebted to Clive Winmill of Badger's Keep Nursery, Chewton, Victoria and Keith Robertson (Creswick, Victoria), apple enthusiast, for help and hints on old apple cultivars in Australia, to Emma-Jane Lamont and Alison Lean of Wye College, University of London for collecting material at Brogdale, to Dick Brummitt (K) and Dan Nicolson (US) for nomenclatural guidance, to Stefan Dressler for information on old German texts, to Stephen Heyworth for guidance in the works of Pliny, to Surrey Jacobs, who kindly shared with us the fruits of his researches connected with the planting of the First Farm Display in the Royal Botanic Gardens Sydney, to G. Aymonin (P) for help with old French words and to M. and Mme J.-P. Boivin of the Service des Cultures, Jardin des Plantes, Paris, for their help with getting to grips with the French pomological literature. Thanks are also due to Heinz Schneider (BAS), Arnis Seisums (RIG), Walter Gams (Baarn), Sarah Juniper (UK), and an anonymous reviewer, who provided very helpful comments on the first draft of the paper.

\section{References}

Audibert Frères (1825) Catalogue des arbres, arbrisseaux, arbustes, et plantes, cultivés dans les pépinières et serres des Frères Audibert. (Huzard: Paris).

Bauhin, C. (1623) Prodromus theatri botanici (Basileae).

Bauhin, J. \& Cherler, J.H. (1650) Historia plantarum universalis, vol. 1. (Ebroduni).

Blackwell, E. (1747-1773) Herbarium blackwellianum. (Nürnberg).

Bock, H. (1552) De stirpium... commentariorum libri tres. (Argentorati).

Borkhausen, M.B. (1797) Ueber die linneischen Gattungen Crataegus, Mespilus, Sorbus, Pyrus und Cydonia. Arch. Bot. 1(2): 85-91.

Borkhausen, M.B. (1803) Theoretisch-praktisches Handbuch der Forstbotanik und Forsttechnoilogie, vol. 2. (G.F. Heyer: Darmsdtadt).

Browicz, K. (1972) Malus Miller in P.H. Davis (ed.) Flora of Turkey and the East Aegean Islands, vol. 4: 157-159. (Edinburgh University Press: Edinburgh).

Browning, F. (1998) Apples. (North Point Press: New York).

Carrière, E.-A. (1879) Un nouveau sujet pour greffer les pommiers. Rev. Hort. 54: 436-7.

Corner, E.J.H. (1946) Suggestions for botanical progress. New Phytol. 45: 185-192.

Decaisne, J. \& Naudin, C. (n.d.) Manuel de l'amateur des jardins, vol. 4. (Didot: Paris).

Desfontaines, R.L. (1809) Histoire des arbres et arbrisseaux, vol. 2. (J.A. Brosson: Paris).

Dioscorides (1552) Anazarbei de medicinali materia libri quinque. (Lugduni).

Ghora, C \& Panigrahi, G. (1995) The family Rosaceae in India, vol. 2. (Bishen Singh Mahendra Pal Singh: Dehra Dun).

Given, D.R. \& Sykes, W.R. (1988) Malus. Pp. 1084 - 1086 in C.J. Webb, W.R. Sykes \& P.J. GarnockJones (eds) Flora of New Zealand, vol. 4 (D.S.I.R.: Christchurch).

Greuter, W., McNeill, J., Barrie, F.R., Burdet, H.M., Demoulin, V., Filgueiras, T.S., Nicolson, D.H., Silva, P.C., Skog, J.E., Trehane, P., Turland, N.J. \& Hawksworth, D.L. (eds) (2000) International Code of Botanical Nomenclature (Saint Louis Code). Regnum Vegetabile 138. (Koeltz: Königstein).

Harden, G.J. \& Rodd, A.N. (1990) Malus in G.J. Harden (ed.) Flora of New South Wales, vol. 1. (New South Wales University Press: Kensington).

Hatton, R.G. (1917) Paradise apple stocks. J. Roy. Hort. Soc. 42: 361-399.

Kartesz, J.T. \& Gandhi, K.N. (1992) Nomenclatural notes for the North American Flora. XI. Phytologia 73: 124-136.

Korban, S.S. \& Skirvin R.M. (1984) Nomenclature of the cultivated apple. HortScience 19: 177-180.

Mabberley, D.J. (1987) The Plant-book. (Cambridge University Press: Cambridge).

Mabberley, D.J. (1997a) The Plant-book, edn 2. (Cambridge University Press: Cambridge).

Mabberley, D.J. (1997b) A classification for edible Citrus (Rutaceae). Telopea 7: 167-172.

Mabberley, D.J (2000) Arthur Harry Church: the anatomy of flowers. (Merrell \& The Natural History Museum: London).

Mansfeld, R. (1986) Verzeichnis landwirtschaftlicher und gärtnerischer Kulturpflanzen (ohne Zierpflanzen), vol. 1. (Springer: Berlin etc.). 
Maxwell, H.S., Knees, S.G. \& Gardner, M.F. (1988). Malus. Pp. 408-12 in J. Cullen \& al. (eds) The European garden flora, vol. 4. (Cambridge University Press: Cambridge).

Medikus, F.C. (1793) Geschichte der Botanik unserer Zeiten. (Mannheim).

Miller, P. (1768) The gardeners dictionary, edn 8. (London).

Moench, C. (1794) Methodus plantas horti botanici et agri marburgensis. (Marburg).

Poiret, J.L.M. (1804) in J.B.A.P.M. de Lamarck, Encyclopédie méthodique. Botanique, vol. 5. (Panckoucke: Paris).

Rehder, A. (1949) A bibliography of cultivated trees and shrubs hardy in the cooler temperate regions of the northern hemisphere. (Arnold Arboretum: Massachusetts).

Reichard, J.J. (1779) Systema naturae plantarum, vol. 2 (Francofurti ad Moenum).

Robinson, J.P., Harris, S.A. \& Juniper, B.E. (2001). Taxonomy of the genus Malus Mill. (Rosaceae) with emphasis on the cultivated apple. Plant Syst. Evol. 226: 35-58.

Rumsey, H.J. (1924) Granny Smith. Farmer and Settler and Livestock Breeder's Journal 19(22): 13.

Société National d'Horticulture de France, Section Pomologique (1907) Les meilleurs Fruits au Début du Xxe Siècle. Paris.

Spooner, D.M., Anderson, G.J. \& Jansen, R.K. (1993) Chloroplast DNA evidence for the interrelationships of tomatoes, potatoes and pepinos (Solanaceae). Amer. J. Bot. 80: 676-688.

Spurway, J. (n.d.) Granny Smith and her apple. [Ryde] Library \& Information Services Local Studies Leaflet Series no. 2.

Symon, D.E. (1986) Malus. Pp. 439-40 in J.P. Jessop \& H.R. Toelken (eds) Flora of South Australia, edn 4, vol. 1 (South Australian Government Printing Division: Adelaide).

Terpó, A. (1988) Malus. Pp. 66-7 in T.G. Tutin \& al. (eds) Flora europaea, vol. 2. (Cambridge University Press: Cambridge).

Terrell, E.E., Broome, C.R. \& Reveal, J.L. (1983) Proposal to conserve the name of the tomato as Lycopersicon esculentum P. Miller and reject the combination Lycopersicon lycopersicum (L.) Karsten (Solanaceae). Taxon 32: 310-314.

Tournefort, J.P. (1700) Institutiones rei herbariae, vol. 1 (Typographia Regia: Paris).

Tucker \& Co. [1938] Milestones. (Tucker \& Co. Pty. Ltd.: Sydney).

Vaughan, J.G. \& Geissler, C. (1997) The new Oxford book of food plants. (Oxford University Press: Oxford).

Walters, S.M. (1961) The shaping of angiosperm taxonomy. New Phytologist 60: 74-84.

Weston, R. (1775) Flora anglicana. (London).

Worlidge, J. (1676) Vinetum britannicum; or a treatise of cider. (London).

Zohary, D. \& Hopf, M. (1988) Domestication of plants in the Old World. (Clarendon Press: Oxford).

Zohary, D. \& Hopf, M. (1994) Domestication of plants in the Old World, edn 2. (Clarendon Press: Oxford).

\section{Manuscript received 30 November 1999 Manuscript accepted 4 April 2001}

